\title{
A Study of Chekhovian Elements in Radi's Drama
}

\author{
Maryam Heydari Fard \\ Faculty of Foreign Languages and Literature, University of Isfahan, Isfahan, Iran \\ E-mail address: m.heydari1989@gmail.com
}

\begin{abstract}
As one of the outstanding Iranian playwrights, Akbar Radi (1939-2007) is known to be influenced by Henrik Ibsen and Anton Chekhov. Occasionally by his critics, he was called as "The Persian Chekhov" but they never expounded comprehensively the details of the given epithet which might be derived from similarities, influences and inspirations among Radi and Chekov. By analyzing these similarity cases, this essay attempts to figure out whether this resemblance is resulted from the conscious impressionability. Or otherwise, the similar life conditions of the authors - which caused their parallel worldviews - are displayed in the world of their plays. By analyzing the social, economical and geographical conditions of the authors' lives and also studying the resemblance of the content of their works which consist of different aspects of characterization in their plays and also examining the structure and diction of their plays; this essay is going to give a comprehensive view of the epithet of "The Persian Chekhov".
\end{abstract}

Keywords: Akbar Radi; Anton Chekhov; Impressiveness; Plays; Similarity; Life's Condition; Characterization; Structure

\section{INTRODUCTION}

One of the prominent playwrights of Iran, Akbar Radi founded and developed modern drama in his country. By the beginning of his career as an author, he wrote a number of short stories with the same atmosphere of his subsequent plays; so did Chekhov. In his country, Iran, by many of his critics, he is known as mostly been impressed by Chekhov and Ibsen, insomuch that some of the critics named him "The Persian Chekhov"; an epithet that can be defined and explained contrarily. A group of critics believe that Radi in Iran is as considerable and significant author as Chekhov in Russia, while others claim that Radi's plays are just the adapted copies of Chekhov's plays. Radi, himself, remarkes: "... an artistic shade can be felt upon my plays, a Russian tinge, Chekhov's trace ...." (qtd. in Talebi 436). Hamedih Onqa, Radi's wife, in her memoir, notes: " whilst, I was setting our furniture in our small home and Radi was arranging his books, he gave me some pictures and said: 'I want you to set these pictures on my room's wall; Chekhov, Ibsen and Hedayat, however, without those pictures, I am floating in their world."' (Talebi 29). Radi's response to an interviewer's question is notable, who asked him "It is said that in some of your plays, you are influenced by the Russian play writer, Chekhov. In your opinion, to what extent is that right?".

He answered: "I come from the north [of Iran], the area of rain, indolence and grief. And Chekhov, display lucid impression from these dramatic materials with the same indolence and grief, especially in his long plays. Indeed, Chekhov aroused my instinct of nostalgia. This is 
why I sometimes roamed around him.... After all, others experienced and we, for accelerating our work- I emphasize-, are forced to use some of their experiences." (Radi 1973, 71)

Notwithstanding all these polemics, this essay believes that between Radi's and Chekhov's plays, there are similarities both in content and structure and this is indisputable. By analyzing these resemblances, this essay attempts to figure out as to whether the similarities among these two authors' plays are resulted from Radi's conscious impressionability and his plays are just simply the adapted copies of Chekhov's plays, according to what some of his critics claim; or otherwise, their similarity is the consequence of the likeness of their lives and social conditions which led to their similar worldviews and then all these concluded in the similarity of their letters which turned Radi into a great and significant author like Chekhov, for Iranians.

By analyzing both sides of these views; regarding the first one, by studying the content and structure of Radi and Chekhov's plays and about the second view, by considering their biographies and lives' condition, this article attempts to find the verity among this contradiction. Radi once talked about a writer's impressionability procedure when he was asked about the difference between imitation and impressionableness: "These two are really close. Influence of literary works upon us has three phases. The first one is the mere imitation. Second phase is impressionableness and the third is inspiration...." (Mozafari 62).

The aim of this essay is to consider different aspects of both writers' works in order to find the mode and measure of this influence; first by analyzing the biographies of the authors and then by studying the content and structure of their plays.

\section{DISCUSSION}

\section{1. Biography}

Akbar Radi was born in 1939 in Gilan/ Iran. When he had just eleven, out of the chaotic economic condition, his father experienced failure which enforced the family to migrate to Tehran. Likewise, Anton Chekhov had experienced his father's bankruptcy in his childhood and had migrated from his birth town. These migrations are displayed in their plays. These coercive migrations from their birth town to other cities generated an intense nostalgia in them toward their primary home town and birth place. The nostalgic feeling and fascination with their birth town can be noticed in the setting of most of their plays. Their plays' similar settings which are derived from their preoccupation with their foretime and birth town can also have another reason. It is true that both of them had the same fascination with their birth town, but this similarity point could be terminated here if the geographical location and condition of their birth towns were different entirely. The similarity of their birth towns can exceed the similarity of their plays. Akbar Radi was born in Gilan, namely south of the Caspian Sea, and Chekhov was born in Russia, north of the Caspian Sea. The likeness of their plays settings can be raised out of this issue. Setting and location of both author's plays revolve around rural areas that can indicate their nostalgic feeling toward their birth towns. These small cities had similar geographic condition and climate, which are displayed in the cold, cloudy and gloomy atmosphere of the stories that also influenced upon the characters' conduct.

As it was noted, the reason of Radi and Chekhov's migration from their birth place was their families' economic failure. Ghotboldin Sadeghi states:

When Radi started his work, Gilan was at socio- economic crisis. Decay, bankruptcy and economic recess could be found everywhere. Gilan and Tabriz (another city of Iran) was considered as a gate to Europe and owing to this 
territorial correspondence, the economy and reflection of these cities were at the pinnacle of its evolution. These cities were counted as the focus of new thought, policy and economy of Iran. However evolvement of new commercial corresponding ways ... took these cities credits from them and the remained things out of the previous prosper were only tedium, distress and nostalgia for their citizens. (Talebi 500)

In the same way, Chekhov suffered from the chaotic economic condition. Taking an important part of the author's comparative study, the influence of economic issues in their work should be considered. Both of these authors were touched by the economic transition in their lives. Hence, they became keen toward low and middle class of society and displayed these classes' life condition in their works; the matter that has not been seen yet both in Russian and Persian literature. Paying attention to different walks of life, especially low and middle strata in terms of economic condition and displaying it opposed to the high and well off ones, is one of the themes that both author worked on it.

The economic transition is splendidly presented in Chekhov's The Cherry Orchard and On the High Road. In The Cherry Orchard, Ranevsky is a landowner whose bankruptcy is displayed in the play. Her estate is sold to Lopakhin, who was already a serf by his filiations and now out of an economic transformation has reached a fortune and wants to buy Ranevsky'd estate. In the play, On the High Road, Bortsov was a well off landowner in the past and now at this play is a ruined and pitiable broke. Mainly in these plays and in other plays by implication, Chekhov tries to represent the disappearance of bourgeoisie and the possibility of growth of low stratum.

On the other hand, this issue is displayed in Radi's plays in a different way. In Oful (The Descent), Aheste ba Gole-Sorkh (Slowly with the Rose), Labkhand-e-Bashokoh Aghaye Gil (The Glorious Smile of Mr. Gil) and Melody Shahr-e Barany (Melody of a Rainy City), mainly the contrast of the lives of low and high stratum constitute the considerable part of the plays. Radi, by putting these two strata parallelly adjacent, tried to keep himself fair in his plays' atmosphere. By juxtaposing peasantry with property owners in Oful, House's servants with wealthy family of Mr. Gil in Labkhand-e-Bashokoh Aghaye Gil, Jalal, the rustic boy with Sina, the pamper son of Deilami's family in Aheste ba Gole-Sorkh and Mahyar's family with peasant family in Melody Shahr-e-Barany, Radi attempted to display the evil and goodness of both classes. He just wanted to put the charge of judgment on readers without any sympathizing or grouping his characters as black and white.

Another noticeable point in these writers' biographies that can have great influence in their works' comparison is their interest in studying medicine:

Chekhov, himself saw no contradiction between his approach to medicine and his approach to writing, noting that his medical studies had profoundly influenced his literary activity, envisioning science and art as a unity. He saw the goal of both as increasing understanding of life and freeing people from delusions. He wrote: "when a person doesn't understand something, he feels discord within him. Instead of looking for the causes of this discord within himself, as he should, he looks outside. Hence the war with what he does not understand. Gaining insight into life was important in freeing oneself from inner conflict and happiness. (Whyman 16)

Chekhov studied medicine, while Radi, with all his intense desire, couldn't get on to study medicine. Instead, he later studied social science. The same desire of studying medicine also can be seen in Ibsen. Definitely, this interest of learning a realistic science in the writers, whom 
every one of them is great and significant in the literature of their country, cannot be simply passed by. Probably the interest of studying medicine is raised out their beliefs in the necessity of realism in art and literature that this could be seen in their style of writing.

\title{
2. 2. Content of Plays
}

Another aspect, from which the similarity among Anton Chekhov's and Akbar Radi's plays can be analyzed, is their style. A standpoint, which both of them mutually shared, is realism; to be accurate, critical realism. Being lifelike is one of the aims of a realist. Chekhov penned:

\begin{abstract}
After all, in real life people don't spend every minute shooting each other, hanging themselves and making confessions of love. They don't spend all the time saying clever things. They're more occupied with eating, drinking, flirting and talking stupidities - and these are the things which ought to be shown on the stage. A play should be written in which people arrive, go away, have dinner, talk about the weather and play cards. Life must be exactly as it is. And people as they are - not on stilts. ... Let everything on the stage be just as complicated, and at the same time just as simple as it is in life. People eat their dinner; just eat their dinner, and all the time their happiness is being established or their lives are being broken up. (qtd. in Hingley 233)
\end{abstract}

Both writers deemed that their literary works should be representative of people's real lives and palpable for common and illiterate people. The authors' interest in medicine is effective in their realistic viewpoint. Chekhov declares in his letters that the main concern of a writer, like a physician, is the exact diagnosis of maladies and problems. He adds that a writer does not necessarily have any responsibility for offering any solution for the problems. In a letter to his editor Alexi Suvorin, Chekhov articulates a theoretical principle as the basis of his work: "you are confusing two notions, the solution of a problem and the correct posing of the question. Only the second is essential for the artist." (Chekhov 2008, 30). Chekhov forces his viewers to confront their own realities as they watch the characters on stage. He announces that his main objective for writing is to posit people's lives as mirror ahead of them, so by observing the absurdity of characters' lives, they would realize how dull their lives are. Four years before Chekhov's death, he wrote, looking back at his work, "I only wanted to tell people honestly; look, look at how badly you live, how boring are your lives. The important thing is that people should understand this; if they do understand this, they will certainly invent a different and a far better life. Man will become better only once we have shown him as he is." (Chekhov 2008, 31). In his another letter to Alexander Tikhonov in 1902, he states:

\begin{abstract}
All I wanted was to say honestly to people: 'Have a look at yourselves and see how bad and dreary your lives are!'. The important thing is that people should realize that, for when they do, they will most certainly create another and better life for themselves. I will not live to see it, but I know that it will be quite different, quite unlike our present life. And so long as this different life does not exist, I shall go on saying to people again and again, 'Please, understand that your life is bad and dreary!'. (Borny 23)
\end{abstract}

The similarity of their works does not end in their critical realism view; a layer of naturalism can be observed in their plays. Both of them attempted to reveal that to what extent the social condition has influenced upon people's lives. In the naturalistic plays, ordinary people 
are protagonists. In Chekhov and Radi's plays, protagonists are from different walks of life: peasants, servants, teachers, soldiers and etc.

Another view which the authors shared in their plays is impressionism. Both authors' plays concern about the flux of life. They do not just display a slice and segment of life without any motion. The displayed life in their plays is consisted of some details that at the first glance seem irrelevant and extraneous but at the end and from a wider view; it presents a coherent and consistent image. For the first time, it was Leo Tolstoy, who pointed to the similarity between Chekhov's works and Impressionistic paintings. Tolstoy writes: "In Chekhov, everything is real to the verge of illusion. His stories give the impression of a stereoscope. He throws words about in an apparent disorder, like an impressionist painter, he achieves wonderful results by his touches." (Chekhov 2008, 36). And in comparison with an impressionistic painting, he adds:

Chekhov, like the impressionist, has a style all his own. At first glance, it seems as if the painter has merely daubed his canvas with any color that comes to hand, using no discrimination, so that his strokes do not appear to have any relationship. But as soon as one steps back and looks from a distance, one gets the remarkable impression of a colorful, irresistible painting. (Styan 113)

It is also true regarding Radi's works. At first glance, it seems that their works are consisted of irrelevant characters, who are just babbling, but in a general view, all contribute to the theme of the work and aim of the author.

Another issue, which both authors emphasis upon it, is the characterization of their works. Both of the writers put their works' focus not on the narrative line of the story, but on the relationship among the characters that constitute a play. In fact, the story's proceeding is depended on the characters and not on the mere story telling. Generally the actions of plays are raised from characters rather than plot. As an answer to the question that what has the most importance for him in his drama, Radi replies:" For me, more than any other things, characters that would be created on the stage have the highest importance. Of course, other elements do exist and are needed for the play scene, such as setting, plot, theme and things of this sort. But in my opinion, the most important element is character indeed." (Mozafari 26).

Another matter which is immensely important concerning their works is that, plays are not dependent on a hero's life but the proceeding and narrating role of the story is shared among all of the characters. Therefore, all the characters, less or much, are paid attention and there isn't any emphasis on any especial character. None of these authors ever pointed to the characters as absolutely black or totally white. They never did divide the characters into angels and evils for audience and reader. They seek to show both sides of characters to the audience and left the judgment to them. Chekhov writes to Suvorin: "The artist is not meant to be a judge of his characters and what they say; his only job is to be an impartial witness... Drawing conclusions is up to the jury, that is, the readers..." (Whyman 29).

One of the common points in Radi and Chekhov's plays characterization is their concern for intellectuals; the characters who takes no positive action in the story. Ghotboldin Sadeghi points out that the appearance of intellectual characters in drama is due to the horrific incidents and political and economical failures. These dramas are trapped into the characters' prattle (Talebi 500). These characters suffer from disorder and couldn't own anything for themselves and owing to lack of action, they are garrulous. Most of the enlightened and intellectuals in these plays are in conflict with their society. They cannot find their place in the society; become alienated and disappointed, since they are not satisfied with their lives. None of these intellectuals, who philosophize about everything, are the protagonist of their stories; they are just one of all. In Chekhov's, Treplov in The Seagull, Trofimov in The Cherry Orchard, 
Vershinin in The Three Sisters and Astrov in Uncle Vania are of this sort. Trofimov in The Cherry Orchard is one of the characters who display that intellectuals are just man of words, not of action:

Lyubov Andreyevna: You were just a boy then, a charming little student, and now your hair is thin- and spectacles! Is it possible you are still a student?

Trofimov: I shall probably be an eternal student. (Chekhov 1964, 339)

This type of characters can be seen in Radi's plays, as well. One of the wounded enlightened characters of Radi's plays is a teacher named Anush in Rouzane Abi (Blue Aperture). In $O f u l$, he is an idealist engineer called Jahangir Meraj, who is after of making change in a traditional structure of a village. But his efforts are futile. In Dar Meh Be Khan (Sing in Mist), he is an idealist teacher in another village, who is a humanist just by word, and admonishes others but actually is a passive person who cannot do anything for himself. Bamdad in Az Posht-e-Shisheha (From Behind the Windows) and Shaigan in Monji Dar Sobh Namnak (Saviour in A damp Morning) are both disappointed writers who are upset by the government censorship system. All of these enlightened and intellectual characters preach well for others and are good orators. Nonetheless, they are feeble in their actions.

Appearing the character of a doctor is another issue, regarding Chekhov and Radi's plays similarity in characterization. Notably, in almost every plays of Radi and Chekhov's plays, there is a character of a doctor. Generally, these characters are the wisest and the most moderate characters of the plays. The characters of doctors, mostly take the role of positive and good characters of the plays. They talk more wisely and reasonably, in comparison with other characters of the plays. It conveys that they are representative of the author in plays and express his opinions in their dialogues. This also can be an indication of Radi and Chekhov's desire of the medicine. Chekhov's Uncle Vania, The Wood Demon, Ivanov, Platonov, Three Sisters and The Seagull and Radi's Oful, Shab Ruye Sangfarsh-e-Khis (A Night on a Damp Path), Labkhand-e-Bashokuh Aghaye Gil and Dar Meh BeKhan (Sing in Mist) are amongst the works that have a character of a doctor.

Another point which confirms the similarity of the content of these author's plays is their characters' familial condition. Both authors in their plays represent families as detached and disjointed. Generally, in most of their plays, familial relationship is the basis of all the play's actions. And this family is usually has disjointed and separated relationships or in confrontation with the play's happenings will be positioned in a devastation flux:

The basis of Radi's plays is familial relationship. This kind of relations constitutes the dominant atmosphere of most of his dramas. ... He analyzed all the familial quarrels in a dramatic way found the trace of all kind of problems in the family. Then he noted that the solution of all these problems and chaos is depended to the recognition of family, its components and all its related issues. (Afshari 302)

The disjointedness of the family indicates the crucial condition of its members. The tense characters of both authors' plays usually opt two ways to end their tough situation. The first out is committing suicide. Suicide is one of the themes that in both authors' works can be seen as an ultimate solution. Death for these characters is a way of evasion and salvation from their merciless and nasty life. Chekhov used the theme of suicide in almost all of his plays. At least, there is one scene of attempting or committing suicide of one of the characters in Ivanov, The Seagull, The Wood Demon, Uncle Vania, Three Sisters and Cherry Orchard. Shaigan is a 
desperate writer whose family deserted him in Monji Dar Sobh Namnak, Milani who was accused of treachery in Oful, Davood who is voluptuous man in Labkhand Bashokuh Aghaye Gil , Etemad who is a desolate dramatist in Cactus and Nushin, the blind girl in Shab Ruye Sangfarsh-e-Khis, all committed suicide in Radi's plays.

The second general denouement of their plays is characters departure from their domicile and family. A home which should be a place for family members' gathering and a soothing abode; in Radi and Chekhov's plays turned into a place for tension and struggle. Characters, instead of taking refuge in their homes and families, made effort in order to escape from their homes.

Characters, who are not satisfied with their situation and life condition and cannot find solace through their family and home, feel isolated among their family and decide to change their situation by leaving their home and family behind. Family cannot be the safe place for the wretched characters whose social life was hurt. They conclude that departure and migration is the ultimate solution to end their current misery condition. In some cases, they will succeed both in Chekhov and Radi's plays such as Uncle Vania, The Cherry Orchard, Rouzaney-e-Abi, Pelekan (Stairway) and Dar Meh Bekhan. But in some other cases the desperate characters end their lives - the authors end the plays - just by the delusion of traveling, then in reality they didn't move even a step from their current place, specifically the sisters in Three Sisters, Treplov in The Seagull and Bamdad in Az Posht-e-Shisheha belong to this group.

\title{
2. 3. Structure of Plays
}

Another aspect, from which the similarity among Chekhov and Radi's plays can be analyzed, is their plays' structure. One of the elements that contribute to the comparison is the language that they choose for their plays' characters. Their plays are constituted of characters from different social strata and each of the characters has their own individualized and particular language. Characters are not the mere imitation of the authors' society's people. Throughout their writing, there is a kind of unique literariness which gives a special tinge to the common people and makes them decent for the authors' style:

\begin{abstract}
It would be important and amazing to mention that the language of none of the characters of Radi's plays is the real and exact language of the people or stratum or group that character belongs to. In other words, the language did not come faithfully from out of the literary work into it. This signifies that Radi did not use recorder or something to imitate real language of common people; Radi did not do a sort of social- linguistic survey in his works. What Radi has done is that he created several diction and style of talking. These dictions remind the audience of the individuals from different social levels. In other words, he made a kind of symbolic wording style that is not the exact stuff but is the reminiscent of the stuff. (Talebi 63)
\end{abstract}

Both Chekhov and Radi have poetic layers in their language that make it unique and distinct. Another element which both authors made use of it in their plays is the factor of repetition. For instance, in their works, in some cases from beginning of the work, there is emphasis on a particular word or sentence by one or some characters. Radi employs the element of repetition in order to highlight some symbols and emphasize some special matters. He uses this technique to make a kind of relation between different parts of a play and it has different usage in each play.

This matter, which can be called 'leitmotif', tries to direct the reader's attention to the aimed issue of the author or somewhat the theme of the work; a particular word or sentence 
can be repeated the same through the play or be completed and improved through the process of the story. Chekhov in the first act of Three Sisters used the word 'Moscow' for eleventh times in order to emphasize on a specific image from the beginning of the play. This sign is associated with the sisters' desire to travel to Moscow and change their condition and also their inability to do so, from the opening of the story.

Another example from Three Sisters is the repetition of Masha's line from Pushkin throughout the play and it represents the fallibility of her mind and again, it can recall their forgetfulness because they were trapped in their routine lives (Bloom 99). In Radi's Az Posht$e$-Shisheha, in the second half of the play the word of 'Miz' (table) represent the sound of buzz in Persian language which relates to personality of the pretending characters of Mr. and Mrs. Derakhshan.

Another example of this technique in the same play is the repetition of the word 'flower' that is dried and decayed and it associates with heroine of the play -Maryam (Bamdad's wife) - that is decayed and depressed in the lonesome and insipid house of Bamdad. It also represents her nostalgia for her past life as she said: "When I was a child, those days, our garden was full of chrysanthemums .... In the evenings, a delicate sound of music was heard. Flowers seemed to be awakened by the music." (Radi 2007, 386). Radi explains about the technique of repetition in his plays:

Sometimes we bring a word or phrase or even a sentence in an incomplete form in part of a text, then repeat it for emphasis few pages later. Hence, we postpone a fact and in next pages bring it a bit more precise and effective in another way. In a two hour play, we may consciously repeat a matter five times in the form of a word or phrase and then hit the last strike properly. (Mozafari 34)

One of the other elements which both authors applied in their plays is humor. The subjects of both authors' plays are serious and to some extent tragic issues (tragedy in the modern form). Nonetheless, none of the authors provoke the bitterness of the subjects; yet, they try to subtilize these scenes with humorous instances. "Chekhov's characters in Three Sisters and indeed in all of his four major plays, behave in a ridiculously unreasonable way in face of social situation in which they find themselves. [...] Because they do nothing effective to alter their situation, Chekhov's characters become, at least potentially, the objects of comedy's critical laughter" (Borny 200). One of the characters who make such situations in Three Sisters is Ferapont. One of these instances is the dialogue of Andrei and Ferapont in spite of Ferapont's dumbness:

Andrei: Good morning, grandfather. What have you to say?

Ferapont: The Chairman sends a book and some documents or other. Here....

[Hands him a book and a packet.]

Andrei: Thank you. It's all right. Why couldn't you come earlier? It's past eight now.

Ferapont: What?

Andrei: [Louder]. I say you've come late, it's past eight.

Ferapont: Yes, yes. I came when it was still light, but they wouldn't let me in. They said you were busy. Well, what was I to do. If you're busy, you're busy, and I'm in no hurry. [He thinks that ANDREY is asking him something] What? Andrei: Nothing. [Looks through the book] To-morrow's Friday. I'm not supposed to go to work, but I'll come - all the same... and do some work. It's dull at home. [Pause] Oh, my dear old man, how strangely life changes, and how it deceives! To-day, out of sheer boredom, I took up this book - old 
university lectures, and I couldn't help laughing. My God, I'm secretary of the local district council, the council which has Protopopov for its chairman, yes, I'm the secretary, and the summit of my ambitions is - to become a member of the council! I to be a member of the local district council, I, who dream every night that I'm a professor of Moscow University, a famous scholar of whom all Russia is proud! Ferapont: I can't tell... I'm hard of hearing....

Andrei: If you weren't, I don't suppose I should talk to you. I've got to talk to somebody, and my wife doesn't understand me, and I'm a bit afraid of my sisters[...].( Chekhov 1964, 257)

Radi, in response to the question about humor and how much he believes in humor in artistic diction, noted: "Almost all of my plays, even the most serious one of them, have a layer of comedy and humor whether in dramatic situation or dialogues .... It is my belief that in the most serious plays that are almost dark, there should be a little break time to rest and a chance for breathing for the audience in order to follow the more serious and profound issues" (Mozafari 115). He describes his humor as "a kind of sarcasm and bitter laugh. In other word, this is a bitterness that has a sweet chocolate coating on it. On the surface, it is sweet with mirth, airiness and laughter but when one reaches to the kernel, then perceives the bitterness with contemplation." (ibid).

The structure and formation of the plays are organized alike. Both authors start their plays by introducing their characters in the first act. None of the characters will disappear or fade in the later acts and the audience would not face any new character in the middle of the play. The middle acts are usually about the struggle and events that happen among characters form the climax of the play. And as typical and similar in both authors' plays, the last act is the place to end all the quarrels.

\section{CONCLUSIONS}

As it was stated, the similarity between Akbar Radi's plays with Anton Chekhov's ones was indicated several times in different critiques, in so far as Radi was called "The Persian Chekhov", named after Anton Chekhov. But none of these critiques studied the details and elements of this likeness thoroughly. This essay aimed to analyze this similarity from diverse aspects, in order to recognize whether this resemblance - by Radi's side because of his regency - was consciously intended and Radi's works were merely a copy of Chekhov's works or the sameness of Radi's life's condition to Chekhov, resulted in the sameness of his works as well. This article attempted to study this issue in three phases. First, the biography of both authors was the base of analyzing their works' similarity. Then the content and in the last step, the structure of their works were put under study. Taken together, this study spread a wide view of significant elements in both authors' works and suggests that Chekhov's influence in Radi's life and works can be realized both directly and indirectly. However, this essay does believe in the greatness and authority of Akbar Radi and Anton Chekhov and places Radi - in spite of his regency - equal to Chekhov. Because of Chekhov's implicit and explicit influences, Radi can be recognized as one of dozens writers whom benefited from Chekhov's experiences. Also Radi could be called as the father of modern drama of Iran since he presented a new view of drama to Iran and Iranians, the same as Chekhov was called to the world. 


\section{References}

[1] Afshari Eraj. "The Role of Family in Akbar Radi's works". Collection of Essays of First Radi Conference. Ed. Ataollah Coopal. Tehran: Ghatreh Publication, 2010.

[2] Bloom Harold. Bloom's Modern Critical Views: Anton Chekhov. New York: Yale University, 2009.

[3] Borny Geoffrey. Interpreting Chekhov. Australia: ANV, The Australian National University Press, 2006. 30-36.

[4] Chekhov Anton. The Major Plays. Trans. Ann Dunningan. New York: Signet Classics, 1964.

[5] Chekhov Anton, Piero Brunello and Lena Leneck. How to Write Like Chekhov: Advice and Inspiration, straight from his own letters and work. Cambridge: Da Capo Lifelong, 2008.

[6] Hingley Ronald. Chekhov: A Biographical and Critical Study. New York: Barnes \& Nobles, 1966.

[7] Mozafari Mahdi. Behind the Blue Scene, An Interview with Radi. Tehran: Morvarid Publication, 2008.

[8] Radi Akbar. Afar Hand, Essays. Teharn: Omid Publication, 1973.

[9] Radi Akbar. On the Blue Scene. 4 vols. Tehran: Ghatreh Publication, 2007.

[10] Styan John L. Chekhov in Performance. Cambridge: Cambridge University Press, 1971.

[11] Talebi Faramarz. Akbar Radi: A Literary Biography.Tehran: Ghatreh Publication, 2004.

[12] Whyman Rose. Anton Chekhov: Routledge Modern and Contemporary Dramatists. New York: Taylor \& Francis Group, 2010. 